Treasurer: Dr. S. L. Hora, assistant superintendent, Zoological Survey of India, Indian Museum, Calcutta.

Foreign Secretary: Prof. M. N. Saha, professor of physics, University of Allahabad.

Secretaries : Prof. S. P. Agharkar, Ghose professor of botany, University of Calcutta. Dr. A. M. Heron, superintendent of the Geological Survey of India, Indian Museum, Calcutta.

Members of Council: Mr. M. Afzal Hussain, principal of the Punjab Agricultural College, Lyallpur, Punjab; Mr. T. P. Bhaskara Shastri, director of the Nizamiah Observatory, Begumpet, Hyderabad, Deccan ; Dr. S. S. Bhatnagar, university professor of chemistry and director of the University Chemical Laboratories, Lahore; Mr. B. C. Burt, agricultural expert, Imperial Council of Agricultural Research, New Delhi (and Simla); Prof. J. C. Ghosh, head of the Department of Chemistry, University of Dacca, Ramna, Dacea; Dr. F. H. Gravely, superintendent of the Government Museum, Museum House, Egmore, Madras ; Lieut.-Col. R. Knowles, professor of protozoology, School of Tropical Medicine, Calcutta; Dr. K. S. Krishnan, Mahendralal Sircar professor of physics, Indian Association for the Cultivation of Science, 210 Bow Bazar Street, Calcutta; Prof. S. K. Mitra, Khaira professor of physics, University of Calcutta, University College of Science, Calcutta ; Prof. J. N. Mukherjee, Khaira professor of chemistry, University of Calcutta, University College of Science, Calcutta ; Dr. C. W. B. Normand, director-general of observatories, Meteorological Office, Poona 5; Prof. Ganesh Prasad, Hardinge professor of higher mathematics, University of Calcutta; Dr. Baini Prasad, director of the Zoological Survey of India, Indian Museum, Calcutta ; Sir C. V. Raman, director of the Indian Institute of Science, Bangalore; Lieut.Col. S. S. Sokhey, director of the Haffkine Institute, Parel, Bombay; Lieut.-Col. J. Taylor, director of the Central Research Institute, Kasauli (Simla Hills); Mr. S. C. Trevor, president of the Imperial Forest Research Institute, Dehra Dun; Mr. F. Ware, director of the Imperial Institute of Veterinary Research, Muktesar.

The following representatives, in each case a vicepresident and a member of council, of scientific bodies in India were also appointed:

Asiatic Society of Bengal: Sir U. N. Brahmachari, Medical College Hospital (Retired); Mr. C. C.
Calder, director of the Botanical Survey of India and superintendent of the Royal Botanic Gardens, Sibpur, Howrah.

U.P. Academy of Sciences : Prof. K. N. Bahl, professor of zoology, University of Lucknow; Prof. A. C. Banerji, professor of mathematies, University of Allahabad.

Indian Academy of Sciences : Prof. B. K. Singh, professor of chemistry, Ravenshaw College, Cuttack; Dr. K. V. A. Krishnan, bacteriological research officer, School of Tropical Medicine, Calcutta.

Indian Science Congress Association: Dr. J. H. Hutton, deputy commissioner, Naga Hills, Kohima, Assam; Mr. W. D. West, assistant superintendent of the Geological Survey of India, Indian Museum, Calcutta.

At this first ordinary meeting, eleven papers were read, the titles of which are given below :

(i) "Synopsis of the Pre-Vindhyan Geology of Rajputana" by Dr. A. M. Heron.

(ii) "Physiology, Bionomies and Evolution of the Air-Breathing Fishes of India" by Dr. S. L. Hora. (iii) "Problems of the Solar Corona" by Prof. M. N. Saha.

(iv) "Ionospheric Height Measurements at Allahabad" by Mr. G. R. Toshniwal (communicated by Prof. M. N. Saha).

(v) "On the Electron Theory of Metals" by Dr. R. C. Majumdar, University of Lahore (communicated by Prof. M. N. Saha).

(vi) "On Symmetrical Space with Minimum Rate of Expansion" by Prof. N. R. Sen.

(vii) "New Facts regarding Infection of Citrus colletotrichum gleosporoides" by Dr. H. Chaudhuri, Lahore.

(viii) "Synthetic Enzyme" by Prof. H. K. Sen and Mr. Sobhanlal Banerji.

(ix) "On the Question of the Expansibility of Zero in the Series of Legendre Functions having Nonintegral Parameters" by Prof. Ganesh Prasad.

(x) "On the Cataphoretic Speed and Inorganic Colloids" by Prof. J. N. Mukherjee, Mr. S. G. Chaudhuri and Mr. B. N. Ghosh.

(xi) "Mon and Munda in India and Beyond" by Dr. J. H. Hutton.

It may be confidently expected that the National Institute of Sciences of India will play an increasingly important part in the development of scientific research in India.

\title{
Mechanical Testing of Timber
}

$\mathrm{I}^{\mathrm{N}}$ September 1928 a committee was appointed by the Committee of the Privy Council for Scientific and Industrial Research to report "On the Mechanical Testing of Timber". This report has now been issued (London : H.M. Stationery Office, 1934). The Committee had its origin as a consequence of work done during the War, in connexion mainly with the design of aircraft, when the testing of timber became a matter of particular importance; as was shown by the amazing development in aircraft construction and reliability. In 1920, a report was published under the auspices of the Aeronautical Research Committee "On the Materials of Construction used in Aircraft and Aircraft Engines", by Lieut.-Col. C. F. Jenkin, professor of engineering science in the University of Oxford. Prof. Jenkin had served as director of the Materials Section of the Technical Department, dealing with the production of aircraft under the Ministry of Munitions. Chap. $x$ of the report dealt with the mechanical properties of timber in a comprehensive manner.

The Committee appointed in 1928 consisted of the late Sir Alfred Ewing (chairman), Prof. C. F. Jenkin, Prof. A. Robertson and Messrs. W. D. Douglas and C. J. Chaplin. The terms of reference were taken as implying "an unrestricted review of the testing of timber for strength and elasticity". This necessarily included consideration in detail of the methods of testing in use at the Forest Products Research Laboratory, Princes Risborough. Various investigations were carried out at this Laboratory during the course of the investigation. Other important experiments were carried out for the Committee by Prof. E. G. Coker in his laboratory at University 
College, London, and by Mr. Douglas at the Royal Aircraft Establishment.

The history of the development of the mechanical testing of timbers is not without interest. The system followed in most laboratories is practically that devised by the United States Forestry Service, and is the outcome of a scheme proposed in 1891 by $\mathrm{Mr}$. B. S. Fernow, then chief of the U.S. Forest Service. At a somewhat earlier date, the Prussian Government had laid down a basis for timber testing; and Fernow stated that the two methods were practically the same, except that in the United States "the need of practically applicable results has been kept in the foreground". "The American system received a further development about 1902 when it was adopted in the newly-established Forest Products Laboratory at Madison, Wisconsin. In 1920, the U.S. Forest Service requested the American Society for Testing Materials to consider the standardising of timber tests, and the methods then formulated were adopted in 1925 by the newly instituted British Forest Products Research Laboratory. Before this, they had been substantially accepted in the procedure of the Forest Products Laboratories in Canada, India and New Zealand. They have also been adopted by Australia, the Federated Malay States and to some extent by Sweden, Poland and Japan.

The Committee points out that its investigations are only concerned with mechanical tests on small 'clear' specimens of timber-that is to say, specimens which are free from knots, shakes or other defects. The work of forest products laboratories, it realises, is concerned with both large and small specimens.

It is impossible here to follow the Committee through the investigation work carried out which enables it to form its conclusions. It should be mentioned that the testing methods in use at the time had been adopted as standard ones and included the British standard specification for methods of testing small clear specimens of timber (No. 3731929) issued by the British Standards Institution. Although from a practical point of view the tests were the best that could have been devised with the knowledge then available, it was generally felt that several of the methods cornmonly employed were open to criticism from a scientific point of view. An opinion in this sense expressed to the Department in 1928 by Prof. C. F. Jenkin led to the appointment of the Committee which has presented the report now before us.

The Committee's Report concludes with the following: "Broadly speaking the several purposes for which mechanical tests for timber are, or may be, undertaken may be classified as follows :-

I. Tests which regard timber from the point of view of the physicist as a material for scientific examination, apart from any intended practical application.

II. Tests which regard timber from the point of view of the engineer as part of a structure that is to be designed to carry certain loads or perform other specified duties.

III. Tests appropriate for the grading of a number of timbers or for judging of their conformity to a given specification."

"Much, but by no means all, of the work of a Forest Products Laboratory falls within the third category and may properly involve methods of testing which would not be appropriate for the first purpose or even the second. On the other hand, tests suitable for the first purpose, or the second, are often attended by difficulties and restrictions which would put them out of court as matters of routine. It is clearly desirable that, subject to these considerations, the interpretation of all tests should be intelligible and their results definite; but it should be recognised that in providing for the various purposes here roughly indicated, tests of widely different character must be contemplated and they will be subject to different canons of criticism."

Timber testing has a growing value in the world of to-day, and the work of this Committee will be received with high approval and gratitude by research centres throughout the world.

\section{National Inland Water Survey}

$\mathrm{T}$ HE paper on "National Inland Water Survey" by Dr. Brysson Cunningham, read at the meeting of the Royal Geographical Society on March 11, set out the scope of a survey required, not merely to serve the responsibilities of the Ministry of Health in regard to water supply for domestic purposes, but also to meet the needs of industry and commerce, the possible development of hydro-electric motive power, the requirements of irrigation, fisheries and navigation, the drainage of low-lying lands, the prevention of floods and other equally important matters. It defined a national survey, in the technical and only satisfactory sense of the word, as a comprehensive and accurate measurement and complete registration, so far as may be practicable, of all the water to be found in a country, whether contained in lakes, rivers, streams, wells, artificial reservoirs, or subterranean strata and cavities. A survey, it stated, should be regarded as a purely scientific undertaking, necessitating special technical knowledge and supervision and in order to ensure its absolute impartiality, where so many different and possibly conflicting purposes are to be served, it should, as recommended by the Committee of the British Association, be conducted by an organisation "independent of any interest in the administration, control or use of water", such an organisation being available in the Department of Scientific and Industrial Research, which is equipped for work of this kind and possesses the essential scientific authority.

Proceeding to outline the programme of a survey, attention was directed, in connexion with rainfall, to the work of the British Rainfall Organization, which for a number of years past has carried out in an admirable manner the superintendence, collection and publication of data. Evaporation and soil absorption have not yet received the degree of attention needed for the purposes of a survey. It is also a regrettable fact that, up to the present time, there has been no department, or central organisation, constituted to deal with direct hydrological measurements of the amount of water actually derived from rainfall. While certain undertakings take gaugings for their own purposes, these are relatively few and the observations are not accessible by the public. The determination of run-off, that is, the bulk of the water which, following rainfall, escapes to the sea, constitutes therefore the greatest field of activity for 